Original Article

\title{
PCR-RFLP Based genetic diversity of Plasmodium vivax genotypes in district Mardan, Pakistan
}

\author{
Diversidade genética baseada em PCR-RFLP de genótipos de Plasmodium vivax no \\ distrito de Mardan, Paquistão
}

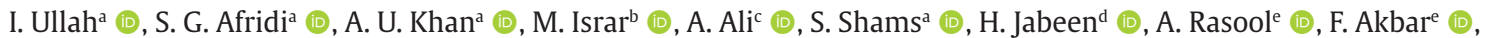

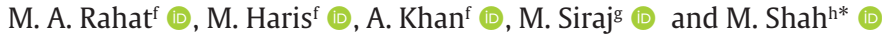 \\ a Department of Biochemistry, Abdul Wali Khan University Mardan, Mardan, Pakistan \\ ${ }^{\mathrm{b}}$ Department of Forensic Sciences, University of Swat, Swat, Pakistan \\ 'Department of Biochemistry, Saidu Medical College, Saidu Sharif, Swat, Pakistan \\ dDepartment of Microbiology, Women University Mardan, Mardan, Pakistan \\ ${ }^{\mathrm{e}}$ Centre for Biotechnology \& Microbiology, University of Swat, Swat, Pakistan \\ ${ }^{\mathrm{f}}$ Department of Genetics, Hazara University Mansehra, Pakistan \\ ${ }^{g}$ Department of Zoology, Abbottabad University of Science \& Technology, Abbottabad, Pakistan \\ ${ }^{\text {h } C e n t r e ~ f o r ~ A n i m a l ~ S c i e n c e s ~ \& ~ F i s h e r i e s, ~ U n i v e r s i t y ~ o f ~ S w a t, ~ S w a t, ~ P a k i s t a n ~}$
}

\begin{abstract}
Plasmodium vivax is the most common human malaria parasite in Asian countries including Pakistan. Present study was designed to explore the genetic diversity of plasmodium vivax genotypes based on Pvmsp-3 $\alpha$ and Pvmsp-3ßgenes using allelic specific nested PCR and RFLP assays markers from field isolates in district Mardan, Pakistan. Blood samples of 200 P. vivax malarial patients were collected after taking their written informed consent. Genetic diversity in nested PCR products was determined by Restriction Fragment Length Polymorphism (RFLP) utilizing Alu1 and PstI restriction enzymes for alpha and beta gene products digestion, respectively. For analysis the genetic diversity of the sub allelic variants of Pvmsp3 $\alpha$ and Pvmsp3 $\beta$ genes, Chi-Square test was performed by utilizing Minitab programming software 18 . The P value 0.05 was considered as statistically significant. For Pvmsp$3 \alpha$ genes after gel electrophoresis of digested products, four distinct genotypes were obtained from total of 50 samples; type A: 35 (70\%) (1.5-2.0 kb), 12 of type B (24\%) (1.5-1.7 kb), 2 of type C (4\%) (0.5-1.5) and one for type D (2\%) (0.5-0.65 kb) which could be characterized into 9 allelic pattern (A1-A4, B1-B3, C1, D), in which A3 remained the most predominant. For Pvmsp-3ßgenes, three distinct genotypes were obtained from 50 samples; $40(80 \%)$ of type $\mathrm{A}(1.5-2.5 \mathrm{~kb}), 9(18 \%)$ of type $\mathrm{B}(1.0-1.5 \mathrm{~kb})$ and $1(2 \%)$ of type $\mathrm{C}(0.65 \mathrm{~kb})$ which could be characterized into 6 allelic patterns (A1-A3, B1-B2, and C1). Most dominant one in Type A was A1 alleles which were noted (46\%), while in Type B, the most dominant were B1 (10\%).This study is the first ever report of molecular epidemiology and genetic variation in Pvmsp-3 $\alpha$ and Pvmsp-3 $\beta$ genes of $P$. vivax isolates by using PCR/RFLP from District Mardan and showed a remarkable level of genetic diversity in the studied genes of circulating parasites in the study area. The results of this study will contribute in future studies about the genetic structure of parasite and vaccine development against the malaria.
\end{abstract}

Keywords: P. vivax, Merozoite surface proteins (MSP), RFLP analysis, Mardan.

\section{Resumo}

O Plasmodium vivax é o parasita da malária humana mais comum nos países asiáticos, incluindo o Paquistão. O presente estudo foi desenhado para explorar a diversidade genética de genótipos de Plasmodium vivax baseados nos genes Pvmsp-3 $\alpha$ e Pvmsp-3 $\beta$, usando marcadores de ensaios alélicos nested PCR e RFLP de isolados de campo no distrito de Mardan, Paquistão. Amostras de sangue de 200 pacientes com malária por $P$. vivax foram coletadas após assinatura do termo de consentimento livre e esclarecido. A diversidade genética em produtos de PCR nested foi determinada por polimorfismo de fragmento de restrição (RFLP) utilizando as enzimas de restrição Alu1 e Pstl para a digestão dos produtos dos genes alfa e beta, respectivamente. Para análise da diversidade genética das variantes subalélicas dos genes Pvmsp3 $\alpha$ e Pvmsp3 $\beta$, o teste Qui-quadrado foi realizado utilizando o software de programação Minitab 18. O valor $\mathrm{P}=0,05$ foi considerado estatisticamente significativo. Para os genes Pvmsp$3 \alpha$, após eletroforese em gel de produtos digeridos, quatro genótipos distintos foram obtidos de um total de 50 amostras; tipo A: 35 (70\%) (1,5-2,0 kb), 12 do tipo B (24\%) (1,5-1,7 kb), 2 do tipo C (4\%) (0,5-1,5) e um para o tipo $\mathrm{D}(2 \%)(0,5-0,65 \mathrm{~kb})$, que podem ser caracterizados em nove padrões alélicos (A1-A4, B1-B3, C1, D), em que

*e-mail: muzafar@uswat.edu.pk,drafridi@awkum.edu.pk

Received: July 23, 2020 - Accepted: September 09, 2020 


\begin{abstract}
A3 permaneceu como o mais predominante. Para Pvmsp-3ßgenes, três genótipos distintos foram obtidos a partir de 50 amostras; $40(80 \%)$ do tipo A (1,5-2,5 kb), 9 (18\%) do tipo B (1,0-1,5 kb) e $1(2 \%)$ do tipo C (0,65 kb), que podem ser caracterizados em seis padrões alélicos (A1-A3, B1-B2 e C1). Os mais dominantes no tipo A foram 0 alelo A1, observados em 46\%, enquanto, no tipo B, os mais dominantes foram B1 (10\%). Este estudo é o primeiro relato de epidemiologia molecular e variação genética em Pvmsp-3 $\alpha$. Os genes Pvmsp-3 $\beta$ de isolados de $P$. vivax utilizando PCR/RFLP do Distrito Mardan mostraram um nível notável de diversidade genética nos genes estudados de parasitas circulantes na área de estudo. Os resultados desse estudo contribuirão em estudos futuros sobre a estrutura genética do parasita e o desenvolvimento de vacinas contra a malária.
\end{abstract}

Palavras-chave: P. vivax, proteínas de superfície de merozoíta (MSP), análise de RFLP, Mardan.

\title{
1. Introduction
}

Malaria is the main threat to public health and it also affects the economic developmental status of many countries (Carlton et al., 2008). Millions of deaths occur every year due to malarial infection and approximately more than $40 \%$ world population living in the malaria infected countries (Tsuboi et al., 2010). Among five species of Plasmodium there are two common species, $P$. vivax and P.falciparum, in which $P$. vivax is highly prevalent species of human malaria parasite globally. Plasmodium vivax is the highly widespread human malaria parasite throughout the world except sub-Sahara region, Africa. In Africa its prevalence is low because of fixation in Duffy negativity trait in Negro population of African peoples (Miller et al., 1976).In Pakistan the malaria burden of $P$. vivax accounts for $92.4 \%$ while $P$. falciparum accounts for $4.7 \%$, so $P$. vivax is the common prevailing specie of malaria parasite. It affects a large proportion of people throughout the country (WHO, 2019). The climate of the district Mardan is hot from May to September and JuneJuly are the hottest months. Precipitation is received often in the year, and the rainstorm season continues from May to October, and August is the rainiest month, thus giving perfect conditions to the advancement of mosquitoes. In 2010, major cases of $P$. vivax and $P$. falciparum were recorded in Sindh district of Pakistan where $P$. falciparum was $18.36 \%$ and $P$. vivax was $81.63 \%$ (Khatoon et al., 2010). Study the population structure is very important to know about the evolution of malaria parasite virulence and the role of parasite genetic diversity in malaria transmission which help in vaccine designing and also helps in impact of malaria control measures (Thakur et al., 2008). Genetic diversity among Plasmodium population is an important sign of the malaria transmission intensity in an area (Babiker et al., 1997). Many number of genes encoding for $P$. vivax as MSPs (merozoite surface proteins), in which Pvmsp-3 $\alpha$ and Pvmsp-3 $\beta$ are highly polymorphic and having huge diversity. Pvmsp-3 $\alpha$ and Pvmsp-3 $\beta$ have also been used as markers in population genetic analysis globally (Mueller et al., 2002; Smith et al., 2012). High level of global traveling and immigration of people from that area where malaria is endemic having incidence of imported cases of malaria has risen. The free traveling and movement of Afghan refugees across the border increase the transmission of malaria in Pakistan (Leslie et al., 2009).The aim of the present study was to investigate the genetic polymorphism and genetic diversity of P.vivax population from malaria endemic area of Mardan, by analyzing the polymorphic molecular markers Pvmsp-3a and Pvmsp-3 $\beta$. In this study of molecular investigation the transmission of P.vivax has been explored by looking at polymorphic genetic markers of Pvmsp-3 alpha and beta genes from the Mardan region of Khyber Pakhtunkhwa, Pakistan.

\section{Material and Methods}

\subsection{Study site and Samples collection}

This research work was done in District Mardan, Pakistan from May 2017 to December 2018. The present study was based on molecular characterization of human $P$. vivax isolates in district Mardan approved by the Board of study (BOS) and advanced studies research board (ASRB) committee of the Department of Biochemistry, Abdul Wali Khan University Mardan. In this research work the patients with the symptoms of malaria in accordance to their response on the pretested questionnaire were selected. Blood collection was done from subjects in Mardan Medical Complex and District Head Quarter Hospital and private diagnostic labs. Both males and females of all ages were the target of this study. Total 200 blood samples were taken from positive patients with the help of lab technician cooperation. After obtaining their written informed consent $5 \mathrm{ml}$ of blood was collected from all malarial patients in EDTA tubes. These samples were confirmed by Giemsa stained based thick and thin layer microscopy. These blood samples were shifted to molecular Biology lab in the Department of Biochemistry, AWKUM (Abdul Wali Khan University Mardan) and stored in the refrigerator at $-20^{\circ} \mathrm{C}$ till the DNA extraction. In this research work fifty samples were amplified for gene MSP3 $\alpha$ (Pvmsp-3 $\alpha)$ andMSP3 $\beta$ (Pvmsp-3 $\beta$ ) alleles.

\subsection{Genomic DNA Extraction}

All positive blood samples of $P$. vivax were subjected to DNA extraction by using Phenol-Chloroform method (Renshaw et al., 2015). The isolated Genomic DNA of all samples was subjected to gel electrophoresis using Ultraviolet (UV) gel documentation (Gel Doc) system. Extracted DNA products were analyzed by $2 \%$ agarose gel stained with ethidium Bromide. Electrophoresis was performed in TAE buffer.

\subsection{Amplification of $P$. vivaxMSP-3 $\alpha$ and $M S P-3 \beta$}

DNA samples with good quality were further analyzed by PCR using Pvmsp-3 alpha and beta genes specific primers. Two sets of Pvmsp-3 $\alpha$ primers (N1) forward+ 
(N1) reverse were used for initial PCR and for Nested PCR Pvmsp-3 $\alpha$ (N2) forward, (N2) Pvmsp-3 $\alpha$ reverse primers were used. Similarly, forPvmsp-3 $\beta$ genes confirmation two sets of primers (N1) forward (N1) reverse were used for initial PCR and for Nested PCRPvmsp-3 $\beta$ (N2) forward (N2) reverse primers were used. For PCR $12 \mu \mathrm{L}$ of PCR water, $10 \mu \mathrm{L}$ of Solis Biodyne Master-mix were taken in PCR tubes then $1 \mu \mathrm{L}$ of forward and reverse primers of eachPvmsp-3 $\alpha$, Pvmsp-3 $\beta$ gene were taken in these tubes were mixed and $2 \mu \mathrm{L}$ of particular individual extracted DNA was taken for initial PCR. The initial denaturation was done at $95{ }^{\circ} \mathrm{C}$ for 5 minutes, annealing was done for alpha gene at $55^{\circ} \mathrm{C}$ for 30 seconds and for beta gene annealing was done at $53-54^{\circ} \mathrm{C}$ for 40 seconds 35 cycles for denaturation was done for 5 minutes and extension was done at $72{ }^{\circ} \mathrm{C}$ for 1 minute.

\subsection{Visualization of $P C R$ products by Gel Electrophoresis}

To observe amplified DNA PCR fragments were resolved by $2 \%$ agarose gel visualized with ethidium bromide and $1 \mathrm{~kb}$ DNA ladder was utilized to affirm the exact size of amplified fragments. The amplified PCR bands were captured at a wavelength of $254 \mathrm{~nm}$ using UV gel documentation system.

\subsection{PCR/RFLP Restriction Fragment Length Polymorphism Analysis}

Restriction fragment length polymorphism of Nested PCR was done by this method for the fragments digestion to show polymorphism by using different digestive enzymes. For Pvmsp-3a genes digestion, Alu1 restriction enzymes were used and for Pvmsp-3 $\beta$ genes digestion, PstI restriction enzymes were used. In this method $18 \mu \mathrm{L}$ PCR water was taken and $10 \mu \mathrm{L}$ Nested PCR products were mixed in PCR tubes. In this mixture $2 \mu \mathrm{L}$ Alu1 restriction enzymes buffer were added for alpha products digestion and $2 \mu \mathrm{LPstI}$ restriction enzymes were added for beta gene products digestion. These tubes were incubated at $37{ }^{\circ} \mathrm{C}$ for 4 hours. After reaction RFLP products were run in $2 \%$ agarose gel and were visualized under UV Trans-illuminator using ethidium bromide.

\subsection{Statistical analysis}

Statistical data and frequencies of $P$. vivax segregates were analyzed by Chi square test at a measurable centrality dimension of $\mathrm{P}<0.05$ utilizing Minitab Programming Software 18.

\section{Results}

Out of 200 malaria infected patients, 101 were female patients while 99 were male patients in which 48 female patients and 62 male patients belong to Katlang region. Samples collected from Mardan Medical Complex (MMC) were 56 in which 35 were female and 21 were male patients. Another 34 samples collected from District Headquarter (DHQ) Mardan included 18 female and 16 male patients. The frequency of female patients was more than male. Among 200 samples, 150 samples were found to be positive for P. vivax by both microscopy and PCR. The Pvmsp-3 $\alpha$ allele was successfully amplified for 50P.vivaxsamples while Pvmsp-3 $\beta$ was also amplified for 50 samples in this study (Table 1 and 2).

\subsection{Amplification of Pvmsp-3a genes by PCR}

Fifty (50) malaria samples were amplified for Pvmsp-3 $\alpha$ genes and were identified for different genotypes. In this study we observed four PCR length variants A, B, C, D. Thirty five of type A (70\%), 12 of type B (24\%), 2of type C (4\%) and one for type D (2\%) (Figure 1 ).

\subsection{PCR-RFLP analysis of Pvmsp-3 $\alpha$}

From RFLP analysis of Pvmsp-3 $\alpha, 9$ types of alleles were detected in current study including Type $A$ with 4 subtypes (A1, A2, A3, A4) fragment size ranged $1.5-2.0 \mathrm{~kb}$ showing frequency of $70 \%$,threeType B (B1, B2, B3) alleles with $24 \%$ frequency, one Type $C(0.5-1.5) 4 \%$ and one Type $D(0.5-$ $0.65 \mathrm{~kb}) 2 \%$. Most dominating one genotype was Type A3 (28\%) followed by A1 (18\%) and then A4 (14\%) (Figure 2).

\subsection{Amplification of Pvmsp-3ßgenes by PCR}

Fifty Malaria samples were amplified for Pvmsp-3ß genes and were identified for different genotypes. In this study we observed three PCR length variants A, B, C. Forty (40) of type $A(80 \%)$, nine of type $B(18 \%)$ and one of type $C(2 \%)$ (Figure 3 ).

\subsection{PCR-RFLP analysis of Pvmsp-3 $\beta$}

From RFLP analysis of Pvmsp-3 $\beta$, 6types of alleles were detected in current study including Type A with

Table 2. Location wise incidence of malaria in District Mardan.

\begin{tabular}{cccc}
\hline S. No. & Source & P. vivax cases & Percentage \\
\hline 1 & Hospital & 111 & $55.5 \%$ \\
2 & Laboratories & 89 & $44.5 \%$ \\
Total & & 200 & $100 \%$ \\
\hline
\end{tabular}

Table 1. Characteristics summary of total study.

\begin{tabular}{lcccc}
\hline S. No. & $\begin{array}{c}\text { Total infected blood } \\
\text { samples }\end{array}$ & Female & Male & Region \\
\hline 1 & 110 & 48 & 62 & Katlang \\
2 & 56 & 35 & 21 & MMC* $^{*}$ \\
3 & 34 & 18 & 16 & DHQ $^{* *}$ \\
Total & 200 & 101 & 99 & \\
\hline
\end{tabular}

${ }^{*}$ MMC (Mardan Medical Complex); ${ }^{* *}$ DHQ (District Health Officer). 


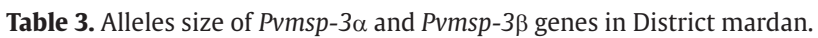

\begin{tabular}{cccc}
\hline Allele $\mathbf{m s p}-\mathbf{3} \alpha$ genes & Size & Allele of msp-3 $\beta$ genes & Size \\
\hline Type A & $1.5-2.0 \mathrm{~kb}$ & Type A & $1.5-2.5 \mathrm{~kb}$ \\
Type B & $1.5-1.7 \mathrm{~kb}$ & Type B & $1.0-1.5 \mathrm{~kb}$ \\
Type C & $0.5-1.5 \mathrm{~kb}$ & Type C & $0.65 \mathrm{~kb}$ \\
Type D & $0.65 \mathrm{~kb}$ & & \\
\hline
\end{tabular}

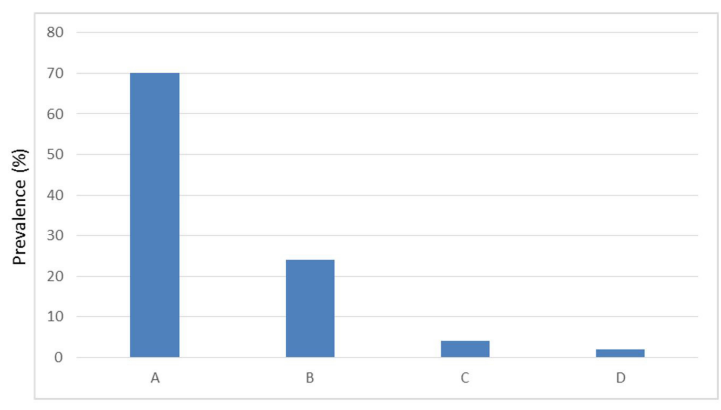

Figure 1. Prevalence of four different alleles of Pvmsp-3 $\alpha$ (A, B, C and D) from PCR-RFLP

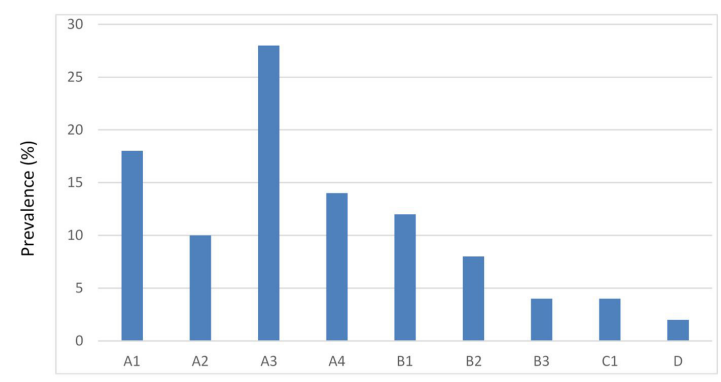

Figure 2. Prevalence of nine different sub-allele types of Pvmsp$3 \alpha(\mathrm{A} 1-\mathrm{A} 4),(\mathrm{B} 1-\mathrm{B} 3), \mathrm{C} 1$ and $\mathrm{D}$ are the nine different alleles from PCR-RFLP.

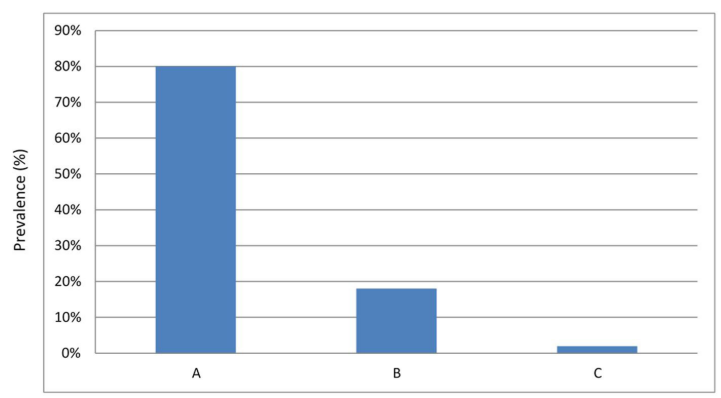

Figure 3. Prevalence of three different alleles of Pvmsp-3 $\beta$ (A, B, C) from PCR-RFLP.

3 sub types alleles (A1, A2 and A3) with fragment size ranged $1.5-2.5 \mathrm{~kb}$ and frequency of $80 \%$, two allele for Type B (B1 and B2) with fragment size ranged $1.0-1.5 \mathrm{~kb}$ and frequency of $18 \%$ and one allele for Type $C(0.65 \mathrm{~kb})$ $2 \%$ were observed (Table 3$)$. Genotype A1 (46\%) was the most abundant followed by A3 (20\%) (Figure 4)

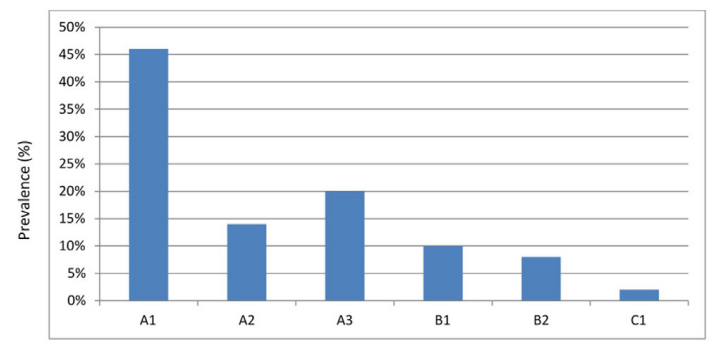

Figure 4. Prevalence of six different sub-allele types of Pvmsp-3 $\beta$ (A1-A3, B1-B2 and C1) based on PCR-RFLP.

\section{Discussion}

Molecular investigation revealed that malaria is one of the most important protozoan diseases after M. tuberculosis infection. Each year approximately 400-600 million malaria cases are reported worldwide with the death rate of 1.52.8 million. According to world malaria report 2017, $12 \%$ of world malaria cases occur in Pakistan. P. vivax population studies have become possible through identification of merozoite surface proteins-3 alpha and beta locus (Verma et al., 2013). In present study total 200 malaria patients were explored including males, females and children were analyzed from May, 2018 to December, 2018. In the present study only fifty samples were detected with four different sizes of PCR products (A, B, C and D) for P. vivax msp-3 $\alpha$. Nine 9 different types of sub-allelic families of Pvmsp-3awere noted in which Type A alleles of P. vivax msp-3 $\alpha$ genes were dominant having four different sub allelic families of Type $A$ (A1, A2, A3 and A4)detected after PCR-RFLP. The band size of Type A for Pvmsp-3 $\alpha$ was (1.7-2.0 kb) with frequency of 70\% (1.5- $1.7 \mathrm{~kb}), 24 \%$ Type C was (0.5- $1.5 \mathrm{~kb}$ ) 4\% and Type D was $(0.65 \mathrm{~kb}) 2 \%$. Pvmsp-3 $\beta$ genes in our results showed three different allele types $(A, B, C)$ in which Type A was dominant having three different sub allelic families of Type A (A1, A2, A3) detected after PCR-RFLP. In our results, 6 different types of sub-allelic families of Pvmsp-3 $\beta$ were noted. The band size of Type A was $1.5-2.5 \mathrm{~kb}$ with frequency of $80 \%$, Type B size was $1.0-1.5 \mathrm{~kb}(18 \%)$ and Type $C$ was $0.65 \mathrm{~kb}(2 \%)$. Our results showed similarities with (Sinka et al., 2013) that recognized four alleles sizes dependent on the length variations of the PCR results of Pvmsp-3 $\alpha$ and three alleles of Pvmsp-3 $\beta$ genes. Highly genetic polymorphism at Pvmsp $3 \alpha$ has also been reported from Korea, Iran, Thailand, South America and Papua New Guinea, thus shows similarities with the present study (Cui et al., 2016, Yasinzai et al., 2004, Bruce et al., 1999, Rayner et al., 2002).Our study differs from hypo endemic northern Iran where type $C$ of the Pvmsp-3 $\alpha$ genes was predominant (Han et al., 2004; Zakeri et al., 2006). In India 
3 different alleles were noted in Pvmsp-3 $\alpha$, Type $\mathrm{A}$ (1.8 kb), Type $B(1.5 \mathrm{~kb})$, and Type $C(1.2 \mathrm{~kb})$. Among these the most predominant one was Type A (75.4\%) followed by Type B (14.3\%) and Type C (10.0\%) (Zakeri et al., 2009). The basic purpose behind indicating a moderate polymorphism is that, Mardan has a huge water system framework. District Mardan has vast irrigation system, after heavy rainfall in monsoon a lot of standing water remains for long which provides ideal environmental condition for mosquito breeding. In the monsoon season from the month of July to November has reported great prevalence of malaria infection. Plasmodium vivax is extensively distributed across Khyber Pakhtunkhwa due to wide agricultural practices, massive irrigation system, and monsoon rainfall. No use of anti-malarial sprays, poor hygienic system, sharing of the housing with livestock, improper diagnosis, poor drainage system, lack of awareness, and load shedding also play a major role in the spread of malaria in district Mardan, Pakistan.

\section{Conclusion}

It is concluded from present study that malaria still remains prevalence in District Mardan. Out of 200 samples, nine types of variants size of alleles were identified in alpha genes and six types of alleles in beta genes. Type $A$ showed high frequency than alleles of type B and C, it means that the parasites show the genetic diversity in district Mardan. Acute attention is needed to carry out further study regarding Pvmsp-3 genes along with other recently explored important vaccine candidate genes diversity to be conducted on mass level with respect to size of samples and regions of infection.

\section{Acknowledgements}

This study was supported by Higher Education Commission of Pakistan under National Research Program for Universities (NRPU) research grant award, NRPU$3474 / 2016$.

\section{References}

BABIKER, H.A., LINES, J., HILL, W.G. and WALLIKER, D., 1997. Population structure of Plasmodium falciparum in villages with different malaria endemicity in east Africa. The American Journal of Tropical Medicine and Hygiene, vol. 56, no. 2, pp. 141-147. http://dx.doi.org/10.4269/ajtmh.1997.56.141. PMid:9080871.

BRUCE, M.C., GALINSKI, M.R., BARNWELL,J.W., SNOUNOU, G. and DAY, K.P., 1999. Polymorphism at the merozoite surface protein-3alpha locus of Plasmodium vivax: global and local diversity. The American Journal of Tropical Medicine and Hygiene, vol. 61, no. 4, pp. 518-525. http://dx.doi.org/10.4269/ajtmh.1999.61.518. PMid:10548283.

CARLTON, J.M., ADAMS, J.H., SILVA, J.C., BIDWELL, S.L., LORENZI, H., CALER, E., CRABTREE, J., ANGIUOLI, S.V., MERINO, E.F., AMEDEO, P., CHENG, Q., COULSON, R.M., CRABB, B.S., DEL-PORTILLO, H.A., ESSIEN, K., FELDBLYUM, T.V., FERNANDEZ-BECERRA, C., GILSON, P.R., GUEYE, A.H., GUO, X., KANG'A, S., KOOIJ, T.W., KORSINCZKY, M., MEYER, E.V., NENE, V., PAULSEN, I., WHITE, O., RALPH, S.A., REN, Q. and SARGEANT, T.J., 2008. Comparative genomics of the neglected human malaria parasite Plasmodium vivax. Nature, vol. 455, pp. 757-763.

CUI, L., MASCORRO, C.N., FAN, Q., RZOMP, K.A., KHUNTIRAT, B., ZHOU, G., CHEN, H., YAN, G. and SATTABONGKOT, J., 2016. Genetic diversity and multiple infections of Plasmodium vivax malaria in Western Thailand. The American Journal of Tropical Medicine and Hygiene, vol. 68, no. 5, pp. 613-619. http://dx.doi. org/10.4269/ajtmh.2003.68.613. PMid:12812356.

HAN, E.T., SONG, T.E., PARK, J.H., SHIN, E.H., GUK, S.M., KIM, T.Y. and CHAI, J.Y., 2004. Allelic dimorphism in the merozoite surface protein-3alpha in Korean isolates of Plasmodium vivax. The American Journal of Tropical Medicine and Hygiene, vol. 71, no. 6, pp. 745-749. http://dx.doi.org/10.4269/ajtmh.2004.71.745. PMid: 15642964.

KHATOON, L., BLAIRIAN, F.N., BENZOIN, M. and MALIK, S.A. and YAN, 2010. Genetic structure of $P$. vivax and $P$. falciparum in the Bannu district of Pakistan. Malaria Journal, vol. 9. pp. 112-126.

LESLIE, T., KAUR, H., MOHAMMED, N., KOLACZINSKI, K., ORD, R.L. and ROWLAND, M., 2009. Epidemic of P. falciparum Malaria Involving Substandard Antimalarial Drugs, Pakistan. Emerging Infectious Diseases, vol. 15, no. 11, pp. 1753-1759. http://dx.doi. org/10.3201/eid1511.090886. PMid:19891862.

MILLER, L.H., MASON, S.J., CLYDE, D.F. and MCGINNISS, M.H., 1976. The resistance factor to Plasmodium vivax in blacks. The Duffy-blood-group genotype, FyFy. The New England Journal of Medicine, vol.295, no. 6, pp. 302-304. http://dx.doi.org/10.1056/ NEJM197608052950602. PMid:778616.

MUELLER, I., KAIOK, J., REEDER, J.C. and CORTES, A., 2002. The population structure of Plasmodium falciparum and Plasmodium vivax during an epidemic of malaria in the Eastern Highlands of Papua New Guinea. The American Journal of Tropical Medicine and Hygiene, vol. 67, no. 5, pp. 459-464. http://dx.doi.org/10.4269/ ajtmh.2002.67.459. PMid:12479544.

VERMA, P., BISWAS, S., MOHAN, T., ALI, S. and RAO, D.N., 2013. Detection of histidine rich protein \& lactate dehydrogenase of Plasmodium falciparum in malaria patients by sandwich ELISA using in-house reagents. The Indian Journal of Medical Research, vol. 138, no. 6, pp. 977-987. PMid:24521645.

RAYNER, J.C., CORREDOR, V., FELDMAN, D., INGRAVALLO, P., IDERABDULLAH, F., GALINSKI, M.R. and BARNWELL, J.W., 2002. Extensive polymorphism in the Plasmodium vivax merozoite surface coat protein MSP-3alpha is limited to specific domains. Parasitology, vol. 125, no. Pt 5, pp. 393-405. http://dx.doi. org/10.1017/S0031182002002317. PMid:12458823.

RENSHAW, M.A., OLDS, B.P., JERDE, C.L., MCVEIGH, M.M. and LODGE, D.M., 2015. The room temperature preservation of filtered environmental DNA samples and assimilation into a phenol chloroform isoamyl alcohol DNA extraction. Molecular Ecology Resources, vol. 15, no. 1. pp. 168-176.

SINKA, M., BANGS, M., MANGUIN, S., RUBIO-PALIS, Y., CHAREONVIRIYAPHAP, T., COETZEE, M., MBOGO, C.M., HEMINGWAY, J., PATIL, A.P., TEMPERLEY, W.H., GETHING, P.W., KABARIA, C.W., BURKOT, T.R., HARBACH, R.E. and HAY, S.I., 2013. A global map of Dominant Malaria Vectors. Parasites E Vectors, vol. 5, no. 1, pp. 69-71. http://dx.doi.org/10.1186/1756-33055-69. PMid:22475528.

SMITH, R., SUWANARUSK, R., COOKE, B.M., DONDORP, A.M., SILAMUT, K., SATTABONGKOT, J., WHITE, N.J. and UDOMSANGPETCH, R., 2012. The Deformability of Red Blood Cells Parasitized by Plasmodium falciparum and P. vivax. The Journal of Infectious Diseases, vol. 189, no. 2, pp. 190-194. PMid:14722882. 
THAKUR, A., ALAM, M.T. and SHARMA, Y.D., 2008. Genetic diversity in the C-terminal $42 \mathrm{kDa}$ region of merozoite surface protein-1 of Plasmodium vivax (PvMSP-1(42) among Indian isolates. Acto Tropica, vol. 108, no. 1, pp. 58-63. http://dx.doi.org/10.1016/j. actatropica.2008.08.011. PMid:18823930.

TSUBOI, T., TAKEO, S., ARUMUGAM, T.U., OTSUKI, H. and TORII, M., 2010. The wheat germ cell-free protein synthesis system: a key tool for novel malaria vaccine candidate discovery. Acta Tropica, vol. 111, no. 3, pp. 171-176. http://dx.doi.org/10.1016/j. actatropica.2009.10.024. PMid:19913490.

WORLD HEALTH ORGANIZATION - WHO, 2019 [viewed 23 July 2020]. World malaria report: 2019 [online]. Geneva Available from: http://www.who.int/malaria/world_malaria report_2019/en/
YASINZAI, M.M., YAQOOB, M., NABI, A. and WASEEM, A., 2004. Determination of sulphite using an immobilized enzyme with flow injection chemiluminescence detection. Luminescence, vol.19. pp. 26-30.

ZAKERI, S., BARJESTEH, H. and DJADID, N.D., 2006. Merozoite surface protein-3alpha is a reliable marker for population genetic $90 \mathrm{~J}$ Vector Borne Dis 47, June 2010 analysis of Plasmodium vivax. Malaria Journal, vol. 5, pp. 50-53.

ZAKERI, S., SAFI, N., AFSHARPAD, M., BUTT, W., GHASEMI, F., MEHRIZI, A.A., ATTA, H., ZAMANI, G. and DJADID, N.D., 2009. Genetic structure of Plasmodium vivax isolates from two malaria endemic areas in Afghanistan. Acta Tropica, vol. 113, no. 1, pp. 12-19. http://dx.doi.org/10.1016/j.actatropica.2009.08.025. PMid: 19716798. 